\title{
Entering adolescence
}

\author{
Calógero Presti*
}

The Brazilian Society of Angiology and Vascular Surgery (SBACV), founded in São Paulo by Doctors Mario Degni and Rubens Carlos Mayall on November $1^{\text {st }}, 1952$, celebrates 60 years of existence, with great tradition and history.

Thirteen years after its foundation, in 1967, SBACV began editing its first journal, Revista Cardiovascular, which was a scientific tool to publicize our specialty for 15 years.

In 1985, because of the great success of the Encontro Paulista de Cirurgia Vascular meeting, Drs Antonio Carlos Simi, Bono Van Bellen and the late dear Prof. Adib Salin Bouabci founded Revista de Angiologia \& Cirurgia Vascular, which was edited by the São Paulo Chapter of the SBACV and was the only scientific journal of our field in Brazil until 2001. Recently, recognizing its historical and scientific importance, our editor-in-chief, Dr. Winston Yoshida, digitalized all the issues of Revista de Angiologia e Cirurgia Vascular and inserted them in the SBACV website.

In 2002, when our society completed 50 years of existence, Professor Marcio Leal Meireles, who was the president of SBACV at the time, wrote the Editorial of Jornal Vascular Brasileiro (JVB) first issue, entitled "Progress and Maturity". In it, he and his editor-in-chief, Professor Telmo Bonamigo, stated their commitment to spreading the knowledge of Angiology and Vascular Surgery in Brazil.

At the time, Professor Telmo Bonamigo was already concerned about the lack of national publications that would reflect the reality in the Brazilian scientific establishment. We did not have publications with Brazilian epidemiological data, and we were forced to rely on data from foreign studies that did not correspond to our reality. According to him, scientific journals had major importance, since they gave their authors, groups and institutions a name, creating tradition and increasing the ability to raise funds and to reveal new academic talents. He understood

that the task of editing the JVB was a commitment of all, and also transferred this responsibility to all members of the SBACV.

Even before completing its first year of existence, J Vasc Bras was already calling attention from abroad. At that time, two members of the International Consulting Board, Professors Roberto Chiesa and Américo Dinis da Gama contributed with the publication of articles in our Journal. At the same time, collaboration programs were created with links to foreign publications, such as the European Journal of Endovascular and Vascular Surgery, Cirujanos Vasculares de Habla Hispana and the Annals of Vascular Surgery.

During Professor Liberato Karaogan de Moura's term as President of the SBACV, the Jornal Vascular Brasileiro was also given priority, and for the first time Guidelines on several vascular problems were published; 20,000 copies of a Special Supplement on POAD, and 10,000 copies on Deep Venous Thrombosis were distributed to members of other specialties across the nation.

In 2005, in the editorial "Path to Consolidation", Dr. Telmo Bonamigo concluded his contribution as Editorin-Chief, and passed on the responsibility to Dr. Winston Bonetti Yoshida, who would soon become one more icon in the history of our Journal. In that same year, Dr. Yoshida proudly informed his peers that Jornal Vascular Brasileiro had been approved by SciELO and qualified as Qualis A-Nacional by CAPES.

After that, Dr. Winston and the Editorial Board took on the great challenge of indexing the journal to MEDLINE.

CAPES has recently implemented a series of changes in the QUALIS system, and downgraded most of the Brazilian journals. Many high quality national publications, which are extremely important to spread scientific information, were depreciated in post-graduation programs, which led to submission of the scientific production to foreign journals, putting at risk the existence of many national journals.

*Cirurgião Vascular e Angiologista do Hospital das Clínicas da Faculdade de Medicina da Universidade de São Paulo (USP); Professor Colaborador da Faculdade de Medicina da USP; Presidente da Sociedade Brasicelira de Angiologia e de Cirurgia Vascular (SBACV) - São Paulo (SP), Brasil.

J Vasc Bras. 2012;11(2):91-92 
Many Brazilian publications have been ignored, even those with a good Impact Factor (IF). CAPES did not have the tools to analyze the IF of national journals, and only gave priority to the journals in QUALIS that were in the Journal Citation Report (JCR), thus condemning all the others to lower levels of evaluation.

In the year 2008, before the new QUALIS classification, JVB had 118 article submissions. After the new classification, this number decreased to 90 , and has remained at that level since. It is estimated that we need 120 submissions a year to ensure the punctuality and quality of the issues.

We need more article submissions in order to achieve indexation to MEDLINE, which will demand sacrifices from researchers, since most of them depend on QUALIS to keep their post-graduation programs.

Another important point is to improve the IF of JVB, that is, the published articles should be read and cited, since CAPES has demonstrated the will to use IF with Scopus in the future to improve the classification of our journal. However, besides publishing more, we also have to read and cite JVB articles.

Despite these difficulties, we are very optimistic about indexing the JVB to MEDLINE, and this will continue to be our main objective as SBACV President. We hope to count on the commitment and support of all.
Congratulations to all of those who have fought and fight for this cause, congratulations to SBAVC, to Dr. Winston Bonetti Yoshida and to JVB Editorial Board for its ten years of existence.

Our journal enters adolescence, and it needs to be strengthened and guided in order to become a mature publication that is able to represent and publicize Brazilian Angiology and Vascular Surgery.

\section{References}

1. Bonamigo TP. No caminho da consolidação. J Vasc Bras. 2004;3(4):295-6.

2. Meirelles M. Rumo à indexação plena. J Vasc Bras. 2007;6(2):109.

3. Moreira RC. Por que os cirurgiões vasculares brasileiros publicam tão pouco? J Vasc Bras. 2008;7(4):291-2.

4. Rocha-e-Silva M. O Novo Qualis, que não tem nada a ver com a ciência do Brasil. Carta aberta ao presidente da CAPES. Clinics. 2009;64:721-4.

5. Yoshida WB. Jornal Vascular Brasileiro: 5 anos. J Vasc Bras. 2009;8(4):289-90.

6. Rocha e Silva M. Qualis 2011-2013: os três erres. Clinics. 2010;65:935-6.

7. Mudança urgente no Sistema QUALIS. J Vasc Bras. 2010;9(1):1-3.

8. Yoshida WB, Holmo NF, Corregliano GT. O Jornal Vascular Brasileiro e os indexadores internacionais. J Vasc Bras. 2011;10(2):101-2. 